\title{
Influence of Claim Management in Construction Industry
}

\author{
Mukilan K., Ramesh babu C., Muthukannan M.
}

\begin{abstract}
Most construction projects are suffering from claims due to many reasons. Claim emergencies have risen for ten years due to the critical political situation. These claims have a bad impact on all groups who were work in the construction field. The impact of claim could be followed to cost overrun, loss of efforts and suspension of work, contract termination. This investigation means to recognize the real reason for causes of claim in construction and demonstrate their difference between respondent concerning individual, company and organization traits. It also aims found the important factors in developing for the management of construction project claim to predict claim occurrence and to mitigate the negative impact of a claim. The objective of the study achieved through a valid questionnaire obtained from several construction companies. The questionnaire survey was conducted involving the contractor, consultant, client point of view. The result of the questionnaire encountered in the SPSS software for finding the major factor that affects the construction. The finding demonstrates the absence of site attention to detect claims, detachment or inaccessible of related documents proactively, and conflicts which develop during owner/contractor negotiation are all critical issue related with the system of claim management. My work aims to distinguish the various claims through review paper and to recognize the most impacted causes of claim in our region.
\end{abstract}

Keywords: Claim, Construction, Management, Regression Analysis, Relative index method (RII).

\section{INTRODUCTION}

The construction field is unique not as same as other industries. It has stressed that the construction industry includes a wide scope of job, workplace, making it interestingly not the same as various industry. One of the real difficulties influencing the construction industry is claims. A claim case is a demand for payment for the destruction caused by any participant in the construction process. Also, the claim is the looking for of thought or change or both by one of the participants to an agreement based an express contract provision.

Revised Manuscript Received on December 15, 2019

* Correspondence Author

Mukilan K., Department of Civil Engineering ,Kalasalingam Academy of Research and Education, Srivilliputhur, Inida . Email: mukicivil@gmail.com

Rameshbabu C., Department of Civil Engineering Kalasalingam Academy of Research and Education, Srivilliputhur, Inida. Email: babussr@gmail.com

Muthukannan M., Department of Civil Engineering Kalasalingam Academy of Research and Education, Srivilliputhur, Inida. Email: civilkannan@gmail.com
Construction claim has a historical impact on the undertaking cost and time. As referenced already, it becomes a heavy load to the industry. Consequently, researchers have put a great deal of time and importance in deciding the reason for that claim. Many construction contributors evaluated the claim construction is one of the most unmanageable matters in the project. Claims are turning in to a lifestyle. The claim mainly arises during the execution of the project and that cause the delay in delivery of the construction. The significantly expanding volume of claim is the consequence of the rising complexity of the project in construction. Development in the construction industry, in reality, is a measure of the economic conditions of a country. The reason behind the claim management is because the industry consumes a wide variety of cash flow; on the other hand, it is opposite to the construction industry: most project exhibit cost overruns, time extensions, and conflicts among parties widely due to claims.

Construction management is the procedure of recruit and co-operating assets to advance a claim from distinguishing proof and examination through readiness, and introduction, before it continues to negotiation and settlement [12]. The primary objective of the research is to list out the claim factors that the construction industry overlay yet to discover the key factor that can fundamentally impact the construction industry. This study distinguishes the key component and possible computation to deal with a claim. All claim cases are seen in the questionnaires survey. The key goal of the claim management is to determine certain issues in a compelling what's the more, proficient way to resolve the claim and to avoid expensive disruption and delays to the project

\section{RESEARCH METHODOLOGY}

The claim is inescapable in the construction industry, and they can exclude or shorten by considering \& understanding their vital causes. Several reasons of claim in construction found in many kinds of literature and research papers, but no one can introduce an important number of claims to prove the normal practice [23]. Reason of claims is unique, and information about them can enhance understanding depends on the factor involved. The perspective of a consultant owner and contractor may change based on how the sensation of claim arises.

The Claim originates from a variety of factors; both direct and indirect [4]. 


\section{Influence of Claim Management in Construction Industry}

Mostly the claim referred to cause a poor investigation of the site, incomplete drawing bid, disruption of construction [16]. In the claim, cost overrun is one of the factors that originate from various sources as order change and unforeseen ground condition [20], [18], demonstrated the claim in construction, such as the delivery of material, weather condition, poor site supervision, insufficient plan \& specification, work acceleration, and schedule problem. [10], [23] also examined the various reason for the claim examined already the(i.e.) scope of work \& change orders during construction. These are the significant reason for the claim. [5] show claim arises from several cases namely defective specifications. [5] Also, demonstrate various reasons for different claim site condition. Change of scope of work, owner causes of disruption or delay [8]. [23] Highlighted the most of these claim caused due to Defect omission in the contract document,[21].Highlighted that causes of claim in the construction industry, including the lack of knowledge, error in construction, unforeseen changes, lack of resources, financial /contractual issues[9] Note that the word claim does not appear in the text of clauses time, for an assertion of entitlement of additional payment. More of the claim can be identified to two origins such an error in the contract document; stakeholder engaged with a project, change condition [10] has found that the most common causes for a claim are design change and error, extra work. A survey study was [20] concluded that the most common causes of claims are increasing in scope, weather condition, and acceleration [20] [21] List some other well-known reason that claim may arise, such as inadequate bid information, fault in drawing and specifications. [15] based on ninety-one projects, the most crucial source of claims include clear or inadequate documentation, inclement weather, time extension assessment. [11] Listed the causes of claims due to ambiguities in the contract document, delay in payment, and change of scope.

This research explored the reason for the claim in the residential project and to recognize factors influencing the claim. To ensure the objective of this research achieved by using a questionnaire survey used to collect the data. The requirement of managing the claim construction is related to all professionals (consultant, contractor, and client) in the construction industry

\section{QUESTIONNAIRE STRUCTURE}

The questionnaire divided into two categories. CategoryI involves the detail about the project and organization to get theinformation about the construction project. The question related to Name of the project, Project value, Start date, Type of project control and End date of the project, etc. Category II involves forty-seven claim factors were identified from literature studies and consulting with some practitioners. These forty-seven factors (i.e.) Category II divided into four subdivisions such as factors related to the contractor, client, consultant, and general categories. The first section (contractor related problem) involves fourteen claim factors such as planning and management, contractual claim, execution error by the contractor. The second section (consultant related problem) involves ten claim factors supervision, the dispute in bill settlement. The third section ( such as delay in design delivery, site management, and

client-related problem ) contains ten factors such as payment to contractors, incomplete design, delay in approval, excessive change ordered, etc. The fourth section ( general factor) contains ten factors such as weather condition, unforeseen ground condition , proper cash flow, sudden change in economic, etc., Using the five-point Likert scale [21], where the range from one to five (1very low, 2-low, 3-medium, 4-high, 5-very high).

\section{DATA COLLECTION}

Questionnaire data distributed around 140 residential projects, but we have received a response from 100 companies out of 140. We received the data from 44 engineers, 18 owners, 22 contractors, 16 consultants on residential as well as commercial projects. They gave the data depending on their experiences, present claim issues in the constructions. These responses were separated based on experience and their position in construction.

\section{DEMOGRAPHIC PROFILE}

Table I: Demographic profile

\begin{tabular}{|c|c|c|c|c|}
\hline $\begin{array}{l}\text { S. } \\
\text { NO } \\
.\end{array}$ & $\begin{array}{c}\text { DEMOGRAPHIC } \\
\text { PROFILE }\end{array}$ & CATEGORY & $\begin{array}{l}\text { NO. OF } \\
\text { RESPNT }\end{array}$ & $\begin{array}{c}\text { PERCEN } \\
\text { TAGE }\end{array}$ \\
\hline \multirow{4}{*}{1.} & \multirow{4}{*}{$\begin{array}{l}\text { Experience in } \\
\text { construction } \\
\text { field }\end{array}$} & $1-5 y r s$ & 27 & 26.7 \\
\hline & & 5-10years & 25 & 24.7 \\
\hline & & $10-20$ years & 23 & 22.7 \\
\hline & & $>20$ years & 26 & 25.7 \\
\hline \multirow{4}{*}{2.} & \multirow{4}{*}{ Job category } & Engineer & 45 & 44.5 \\
\hline & & Owner & 18 & 17.8 \\
\hline & & Proprietor & 16 & 15.8 \\
\hline & & Contractor & 22 & 21.7 \\
\hline \multirow{2}{*}{3.} & \multirow{2}{*}{$\begin{array}{l}\text { Type of project } \\
\text { undertaken }\end{array}$} & Residential & 54 & \multirow{2}{*}{100} \\
\hline & & Commercial & 46 & \\
\hline
\end{tabular}

\section{DATA ANALYSIS}

The data analysed using statistical tools like SPSS (Statistical Package for Social Science) and MS Excel. SPSS is a software package utilised for leading statistical analysis, controlling the data and creating the tables and charts that condense data. SPSS performs statistical analysis run from fundamental descriptive statistics such as factor analysis. Frequency analysis is a descriptive statistical package that shows that the number of events of each response picked by the respondents. We can likewise compute the sum mean median mode etc. 
The gathered data was entered, worked and examined by utilizing the essential standard of statistics. The data was taken care of into required information by simplifying and understanding the appropriate response from the filled-out questionnaire.In the below table the sum is the total number of weighting given by each respondent and RII value calculated by using the formula

$$
\begin{aligned}
& \mathrm{RII}=\square^{W} \\
& N \times A
\end{aligned}
$$

Where RII $=$ Relative Importance Index: $\sum \mathrm{w}=$ weighting given by each respondent: $\mathrm{N}=$ Number of responses received: $\mathrm{A}=$ Highest weight (1 to 5). The rank was assigned based on the RII value.

Table II: Scale of Importance

\begin{tabular}{|c|c|}
\hline Scale of Importance & Scale Value \\
\hline 1 & Very Low \\
\hline 2 & Low \\
\hline 3 & Medium \\
\hline 4 & High \\
\hline 5 & Very High \\
\hline
\end{tabular}

Table III: Ranking for Contractor Related Factors

\begin{tabular}{|c|l|l|c|c|}
\hline S.NO & \multicolumn{1}{|c|}{ DESCRIPTION } & SUM & RII & RANK \\
\hline 1 & Quality of contractor's & 363 & 0.712 & 1 \\
\hline 2 & work & Planning and & & \\
\hline 3 & Management & 340 & 0.672 & 2 \\
\hline 4 & Delay in progress if any & 327 & 0.654 & 3 \\
\hline 5 & Complex execution of & 322 & 0.635 & 4 \\
\hline 6 & Unexpect & & & \\
\hline & Contractual claims & 313 & 0.617 & 6 \\
\hline inflation rates & 317 & 0.623 & 5 \\
\hline
\end{tabular}

\begin{tabular}{|c|c|c|c|c|}
\hline & cost) & & & \\
\hline 7 & $\begin{array}{l}\text { Financial control and } \\
\text { wastage on site }\end{array}$ & 308 & 0.605 & 7 \\
\hline 8 & $\begin{array}{l}\text { Execution error by } \\
\text { contractor. }\end{array}$ & 308 & 0.605 & 7 \\
\hline 9 & $\begin{array}{l}\text { Shortening of contract } \\
\text { period }\end{array}$ & 307 & 0.602 & 8 \\
\hline 10 & $\begin{array}{l}\text { Lack of staff experience } \\
\text { and execution by } \\
\text { contractors }\end{array}$ & 302 & 0.594 & 9 \\
\hline 11 & $\begin{array}{l}\text { Cash flow and financial } \\
\text { difficulties by contractors }\end{array}$ & 299 & 0.591 & 10 \\
\hline 12 & $\begin{array}{l}\text { Incomplete contract } \\
\text { document and their } \\
\text { discrepancies }\end{array}$ & 295 & 0.585 & 11 \\
\hline 13 & $\begin{array}{l}\text { Provision of BOQ \& } \\
\text { dispute during bill } \\
\text { settlement }\end{array}$ & 294 & 0.582 & 12 \\
\hline 14 & $\begin{array}{l}\text { Lack of control over sub- } \\
\text { contractor }\end{array}$ & 291 & 0.571 & 13 \\
\hline
\end{tabular}

The major five factors that should affect the construction from the contractor's sides are

1. Quality of contractor's work

2. Planning and Management

3. Delay in progress if any Variation order

4. Complex execution of the project

5. Unexpected changes in exchange, interest and inflation rates

A. FREQUENCY TABLE:

(Where F- Frequency, P-Percentage, VP- Valid Percentage, CP- Cumulative percentage)

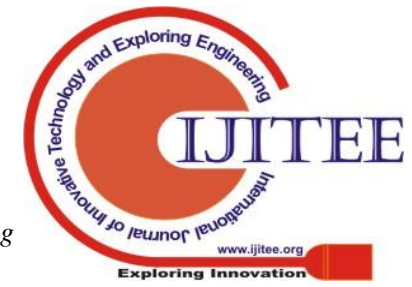


Influence of Claim Management in Construction Industry

Table IV: Frequency Table Quality of Contractors Work

\begin{tabular}{|l|c|c|c|c|}
\hline \multicolumn{5}{|c|}{ QUALITY OF CONTRACTOR'S WORK } \\
\hline VALID & F & P (\%) & VP (\%) & CP (\%) \\
\hline Very low & 20 & 19.0 & 19.0 & 19 \\
\hline Low & 21 & 21.0 & 21.0 & 40 \\
\hline Medium & 20 & 20.0 & 20.0 & 60 \\
\hline High & 26 & 26.0 & 26.0 & 86 \\
\hline Very high & 14 & 14.0 & 14.0 & 100 \\
\hline TOTAL & 101 & 100 & 100 & \\
\hline
\end{tabular}

Table V: Frequency for Planning and Management

\begin{tabular}{|l|c|c|c|c|}
\hline \multicolumn{5}{|c|}{ PLANNING AND MANAGEMENT } \\
\hline VALID & F & P (\%) & VP (\%) & CP (\%) \\
\hline Very low & 13 & 13 & 13 & 13 \\
\hline Low & 10 & 9 & 9 & 22 \\
\hline Medium & 25 & 25 & 25 & 47 \\
\hline High & 31 & 31 & 31 & 78 \\
\hline Very high & 22 & 22 & 22 & 100 \\
\hline TOTAL & 101 & 100 & 100 & \\
\hline
\end{tabular}

Table VI: Frequency For Delay In Progress If Any Variation Orders

\begin{tabular}{|l|c|c|c|c|}
\hline \multicolumn{5}{|c|}{ DELAY IN PROGRESS IF ANY VARIATION ORDER } \\
& & & VP & CP (\%) \\
& & & & \\
\hline VALID & F & & \\
\hline Very low & 12 & 12 & 12 & 12 \\
\hline Medium & 18 & 17 & 17 & 29 \\
\hline High & 24 & 24 & 24 & 53 \\
\hline Very high & 21 & 21 & 21 & 100 \\
\hline TOTAL & 10 & 100 & 100 & \\
\hline
\end{tabular}

Table VII: Frequency for complex execution of project

\begin{tabular}{|l|c|c|c|c|}
\hline \multicolumn{5}{|c|}{ COMPLEX EXECUTION OF PROJECT } \\
\hline VALID & F & P (\%) & VP (\%) & CP (\%) \\
\hline Very low & 10 & 9 & 9 & 9 \\
\hline Low & 21 & 21 & 21 & 30 \\
\hline Medium & 26 & 26 & 26 & 56 \\
\hline High & 27 & 27 & 27 & 83 \\
\hline Very high & 17 & 17 & 17 & 100 \\
\hline TOTAL & 101 & 100 & 100 & \\
\hline
\end{tabular}

Table VIII: Frequency for Unexpected Changes in Exchange, Interest and Inflation Rates

\section{UNEXPECTED CHANGES IN EXCHANGE, INTEREST AND INFLATION RATES}

\begin{tabular}{|c|c|c|c|c|}
\hline VALID & $\mathbf{F}$ & $\mathrm{P}(\%)$ & VP (\%) & $\mathrm{CP}(\%)$ \\
\hline Very low & 13 & 13 & 13 & 13 \\
\hline Low & 16 & 16 & 16 & 29 \\
\hline Medium & 29 & 29 & 29 & 58 \\
\hline High & 25 & 25 & 25 & 83 \\
\hline Very high & 18 & 17 & 17 & 100 \\
\hline TOTAL & 101 & 100 & 100 & \\
\hline
\end{tabular}

B. DESIGN CONSULTANT RELATED

Table IX: Ranking for Design Consultant Related

\begin{tabular}{|c|l|c|c|c|}
\hline S.NO & DESCRIPTION & SUM & RII & RANK \\
\hline 1 & $\begin{array}{l}\text { Difference } \\
\text { between design } \\
\text { and actual quantities }\end{array}$ & 332 & 0.652 & 1 \\
\hline 2 & $\begin{array}{l}\text { Contacts and } \\
\text { ambiguities }\end{array}$ & 325 & 0.641 & 2 \\
\hline & & & \\
\hline & & & \\
\hline
\end{tabular}




\begin{tabular}{|c|c|c|c|c|}
\hline 3 & Site management & 322 & 0.634 & 3 \\
\hline & and supervision & & & \\
\hline 4 & $\begin{array}{l}\text { Relationship } \\
\text { between site } \\
\text { management and } \\
\text { execution team }\end{array}$ & 317 & 0.622 & 4 \\
\hline 5 & $\begin{array}{l}\text { Lack of } \\
\text { coordination } \\
\text { between } \\
\text { construction parties }\end{array}$ & 304 & 0.608 & 5 \\
\hline 6 & $\begin{array}{l}\text { Delay of shop } \\
\text { drawing approval }\end{array}$ & 304 & 0.605 & 5 \\
\hline 7 & $\begin{array}{l}\text { Complete design } \\
\text { and specs }\end{array}$ & 301 & 0.597 & 6 \\
\hline 8 & $\begin{array}{l}\text { Delay in design } \\
\text { delivery }\end{array}$ & 301 & 0597 & 6 \\
\hline 9 & $\begin{array}{l}\text { Dispute on bill } \\
\text { settlement }\end{array}$ & 298 & 0.591 & 7 \\
\hline 10 & $\begin{array}{l}\text { Termination of } \\
\text { contract and } \\
\text { suspension of work } \\
\text { by one party }\end{array}$ & 295 & 0.586 & 8 \\
\hline
\end{tabular}

The major five factors that should affect the construction from design consultant sides are

1. Difference between design and actual quantities

2. Contacts and ambiguities

3. Site management and supervision

4. Relationship between site management and execution team

5. Lack of coordination between construction parties

C. FREQUENCY TABLE

Table X: Frequency for Difference Between Design And Actual Quantities

\begin{tabular}{|l|c|c|c|c|}
\hline \multicolumn{5}{|c|}{ DIFFERENCE BETWEEN DESIGN AND ACTUAL QUANTITIES } \\
\hline VALID & F & P(\%) & VP(\%) & CP(\%) \\
\hline Very low & 11 & 11 & 11 & 11 \\
\hline
\end{tabular}

\begin{tabular}{|l|c|c|c|c|}
\hline Low & 13 & 12 & 12 & 23 \\
\hline Medium & 29 & 29 & 29 & 52 \\
\hline High & 30 & 30 & 30 & 82 \\
\hline Very high & 18 & 18 & 18 & 100 \\
\hline TOTAL & 101 & 100 & 100 & \\
\hline
\end{tabular}

Table XI: Frequency For Contact And Ambiguities

\begin{tabular}{|l|c|c|c|c|}
\hline \multicolumn{5}{|c|}{ CONTACT AND AMBIGUITIES } \\
\hline VALID & F & P (\%) & VP (\%) & CP (\%) \\
\hline Very low & 14 & 14 & 14 & 14 \\
\hline Low & 8 & 7 & 7 & 21 \\
\hline Medium & 36 & 36 & 36 & 57 \\
\hline High & 26 & 26 & 26 & 83 \\
\hline Very high & 17 & 17 & 17 & 100 \\
\hline TOTAL & 101 & 100 & 100 & \\
& & & & \\
\hline
\end{tabular}

Table XII: Frequency For Site Management And Supervision

\begin{tabular}{|l|c|c|c|c|}
\hline \multicolumn{5}{|c|}{ SITE MANAGEMENT AND SUPERVISION } \\
\hline VALID & F & P (\%) & VP (\%) & CP (\%) \\
\hline Very low & 11 & 10 & 10 & 10 \\
\hline Low & 18 & 18 & 18 & 28 \\
\hline Medium & 27 & 27 & 27 & 55 \\
\hline High & 30 & 30 & 30 & 85 \\
\hline Very high & 15 & 15 & 15 & 100 \\
\hline TOTAL & 101 & 100 & 100 & \\
& & & & \\
\hline
\end{tabular}

Published By:

Blue Eyes Intelligence Engineering 
Influence of Claim Management in Construction Industry

Table XIII: Frequency For Relationship Between Design And Actual Quantities

\begin{tabular}{|l|c|c|c|c|}
\hline \multicolumn{5}{|c|}{ RELATIONSHIP BETWEEN DESIGN AND ACTUAL } \\
QUANTITIES & CP (\%) \\
\hline VALID & F & P (\%) & VP (\%) & \\
\hline & & & & 10 \\
\hline Very low & 10 & 10 & 10 & 27 \\
\hline Low & 17 & 17 & 17 & 57 \\
\hline Medium & 30 & 30 & 30 & 89 \\
\hline High & 33 & 32 & 32 & 100 \\
\hline Very high & 11 & 11 & 11 & \\
\hline TOTAL & 101 & 100 & 100 & \\
\hline
\end{tabular}

Table XIV: Frequency Table For Lack of Coordination Between Construction Parties

\begin{tabular}{|c|c|c|c|c|}
\hline \multicolumn{5}{|c|}{ LACK OF COORDINATION BETWEEN CONSTRUCTION } \\
\hline & PARTIES \\
\hline VALID & F & P(\%) & VP (\%) & CP (\%) \\
\hline Very low & & & 14 & 14 \\
\hline Low & 23 & 23 & 23 & 37 \\
\hline Medium & 21 & 21 & 21 & 58 \\
\hline High & 29 & 29 & 29 & 87 \\
& & & & \\
\hline Very high & 14 & 13 & 13 & \\
\hline TOTAL & 101 & 100 & 100 & \\
\hline
\end{tabular}

D. CLIENT RELATED AND ITS FREQUENCIES

Table XV: Ranking of Client Related Factors

\begin{tabular}{|c|c|c|c|c|}
\hline S.NO & DESCRIPTION & SUM & RII & RANK \\
\hline 1 & $\begin{array}{c}\text { Funds } \\
\text { arrangement and } \\
\text { cash } \\
\text { flow }\end{array}$ & 340 & 0.673 & 1 \\
\hline 2 & $\begin{array}{c}\text { Change the order } \\
\text { during } \\
\text { construction and } \\
\text { market } \\
\text { inflations }\end{array}$ & 329 & 0.654 & 2 \\
\hline
\end{tabular}

\begin{tabular}{|c|c|c|c|c|}
\hline 3 & $\begin{array}{l}\text { payment to } \\
\text { contractor }\end{array}$ & 321 & 0.642 & 3 \\
\hline 4 & $\begin{array}{l}\text { A long line of } \\
\text { authority on } \\
\text { owner } \\
\text { organization }\end{array}$ & 319 & 0.633 & 4 \\
\hline 5 & $\begin{array}{c}\text { Ignoring items } \\
\text { with abnormal } \\
\text { rates (tender } \\
\text { evaluation) }\end{array}$ & 319 & 0.633 & 4 \\
\hline 6 & $\begin{array}{c}\text { Excessive } \\
\text { changes in order } \\
\text { and frequent } \\
\text { design change }\end{array}$ & 314 & 0.626 & 5 \\
\hline 7 & $\begin{array}{l}\text { Change of scope } \\
\text { of work and } \\
\text { additional work }\end{array}$ & 305 & 0.605 & 6 \\
\hline 8 & $\begin{array}{c}\text { Delay in } \\
\text { approval of } \\
\text { completed work }\end{array}$ & 305 & 0.605 & 6 \\
\hline 9 & $\begin{array}{l}\text { Incomplete } \\
\text { design at the time } \\
\text { of tender }\end{array}$ & 289 & 0.582 & 7 \\
\hline 10 & $\begin{array}{c}\text { Omission and } \\
\text { error of } \\
\text { BOQ \& } \\
\text { Incomplete } \\
\text { tender } \\
\text { document }\end{array}$ & 287 & 0.575 & 8 \\
\hline
\end{tabular}

The major five factors that should affect the construction from client sides are

1. Funds arrangement and cash flow

2. Change the order during construction and market inflations

3. Payment to contractor

4. The long line of authority on owner organization

5. Ignoring items with abnormal rates (tender evaluation)

E. FREQUENCY TABLE

Table XVI: Frequency For Payment To Contractor

\begin{tabular}{|c|c|c|c|c|}
\hline \multicolumn{5}{|c|}{ LONG LINE OF AUTHORITY BY OWNER ORGANISATION } \\
\hline VALID & F & P(\%) & VP(\%) & CP(\%) \\
\hline Very low & 14 & 14 & 14 & 14 \\
\hline Low & 15 & 15 & 15 & 29 \\
\hline Medium & 21 & 21 & 21 & 50 \\
\hline High & 38 & 38 & 38 & 88 \\
\hline Very High & 13 & 12 & 12 & 100 \\
\hline TOTAL & 101 & 100 & 100 & \\
\hline
\end{tabular}

Table XVII: Frequency for Long Line of Authority

\begin{tabular}{|c|c|c|c|c|}
\hline \multicolumn{5}{|c|}{ PAYMENT CONTRACTOR } \\
\hline VALID & F & P(\%) & VP(\%) & CP(\%) \\
\hline Very low & 9 & 9 & 9 & 9 \\
\hline Low & 22 & 22 & 22 & 31 \\
\hline
\end{tabular}




\begin{tabular}{|c|c|c|c|c|}
\hline Medium & 26 & 26 & 26 & 57 \\
\hline High & 25 & 25 & 25 & 82 \\
\hline Very High & 19 & 18 & 18 & 100 \\
\hline TOTAL & 100 & 100 & 100 & \\
\hline
\end{tabular}

\begin{tabular}{|l|l|l|l|l|} 
& & & & \\
\hline Very high & 18 & 17 & 17 & 100 \\
\hline TOTAL & 101 & 100 & 100 & \\
& & & & \\
\hline
\end{tabular}

Table XVIII: Frequency For Fund Arrangement And Cash Flow

\begin{tabular}{|l|c|c|c|c|}
\hline \multicolumn{5}{|c|}{ FUND ARRANGEMENT AND CASH FLOW } \\
\hline VALID & F & P(\%) & VP (\%) & CP (\%) \\
\hline Very low & 12 & 12 & 12 & 12 \\
\hline Low & 11 & 11 & 11 & 23 \\
\hline Medium & 23 & 23 & 23 & 47 \\
\hline High & & & & \\
\hline Very high & 23 & 22 & 22 & 100 \\
& & & & \\
\hline TOTAL & 101 & 100 & 100 & \\
& & & & \\
\hline
\end{tabular}

Table XIX: Frequency For Ignoring Items With Abnormal Rate (Tender Evaluation)

\begin{tabular}{|l|c|c|c|c|}
\hline \multicolumn{5}{|c|}{ IGNORING ITEMS WITH ABNORMAL RATE (TENDER } \\
EVALUATION) \\
\hline VALID & F & P (\%) & VP (\%) & CP (\%) \\
& & & & \\
\hline Very low & 13 & 13 & 13 & 13 \\
\hline Low & 18 & 18 & 18 & 31 \\
\hline Medium & 23 & 23 & 23 & 54 \\
\hline High & 29 & 29 & 29 & 83
\end{tabular}

\section{GENERAL FACTORS AND ITS FREQUENCIES}

Table XX: Ranking for General Factors and its Frequencies

\begin{tabular}{|c|c|c|c|c|}
\hline S.NO & DESCRIPTION & SUM & RII & RANK \\
\hline 1 & $\begin{array}{l}\text { Unexpected changes in } \\
\text { material price }\end{array}$ & 327 & 0.645 & 1 \\
\hline 2 & $\begin{array}{l}\text { The high cost of labor and } \\
\text { transportation }\end{array}$ & 325 & 0.643 & 2 \\
\hline 3 & $\begin{array}{l}\text { Sudden changes in } \\
\text { economic and market } \\
\text { condition }\end{array}$ & 316 & 0.625 & 3 \\
\hline 4 & $\begin{array}{l}\text { Proper cash flow during } \\
\text { construction }\end{array}$ & 314 & 0.621 & 4 \\
\hline 5 & $\begin{array}{l}\text { Problem with neighbors } \\
\text { around the site }\end{array}$ & 313 & 0.619 & 5 \\
\hline 6 & $\begin{array}{l}\text { Unforeseen ground } \\
\text { condition }\end{array}$ & 313 & 0.619 & 5 \\
\hline 7 & $\begin{array}{l}\text { Unexpected changes in } \\
\text { exchange, interest and } \\
\text { inflation rate. }\end{array}$ & 306 & 0.605 & 6 \\
\hline 8 & $\begin{array}{l}\text { Change in government } \\
\text { regulations and laws }\end{array}$ & 291 & 0.576 & 7 \\
\hline 9 & Weather conditions & 290 & 0.574 & 8 \\
\hline 10 & $\begin{array}{l}\text { Insufficient utilities } \\
\text { available on site } \\
\text { (electricity, water etc..,) }\end{array}$ & 279 & 0.552 & 9 \\
\hline
\end{tabular}

The major factors that should affect the construction are

1. Unexpected changes in material price

2. The high cost of labour and transportation

3. Sudden changes in economic and market condition

4. Problem with neighbours around the site 


\section{Influence of Claim Management in Construction Industry}

A. FREQUENCY TABLE

Table XXI: Frequency For Unexpected Changes In Material

\begin{tabular}{|l|c|c|c|c|}
\hline \multicolumn{6}{|c|}{ UNEXPECTED CHANGES IN MATERIAL PRICE } \\
\hline VALID & F & P (\%) & VP (\%) & CP (\%) \\
\hline Very low & 9 & 9 & 9 & 9 \\
\hline Low & 21 & 21 & 21 & 30 \\
\hline Medium & 26 & 26 & 26 & 56 \\
\hline High & 22 & 22 & 22 & 78 \\
\hline Very high & 22 & 22 & 22 & 100 \\
\hline TOTAL & 101 & 100 & 100 & \\
\hline
\end{tabular}

Table XXII: Frequency For Sudden Changes In Economic And Market Conditions

\begin{tabular}{|l|c|c|c|c|}
\hline \multicolumn{5}{|c|}{ CUDDEN CHANGES IN ECONOMIC AND MARKET } \\
\hline VALID & F & P (\%) & VP (\%) & CP (\%) \\
\hline & & & & \\
\hline Very low & 11 & 11 & 11 & 11 \\
\hline Low & 20 & 20 & 20 & 31 \\
\hline Medium & 26 & 26 & 26 & 57 \\
\hline High & 28 & 28 & 28 & 85 \\
\hline Very high & 16 & 15 & 15 & 100 \\
\hline TOTAL & 10 & 100 & 100 & \\
\hline
\end{tabular}

Table XXIII: Frequency For Problem With Neighbour Around The Site

\begin{tabular}{|l|c|c|c|c|}
\hline \multicolumn{5}{|c|}{ PROBLEM WITH NEIGHBOUR AROUND THE SITE } \\
\hline VALID & F & P (\%) & VP (\%) & CP (\%) \\
\hline Very low & 9 & 9 & 9 & 9 \\
\hline Low & 17 & 17 & 17 & 26 \\
\hline Medium & 40 & 40 & 40 & 66 \\
\hline High & 20 & 20 & 20 & 86 \\
\hline Very high & 14 & 14 & 14 & 100 \\
\hline TOTAL & 100 & 100 & 100 & \\
\hline
\end{tabular}

Table XXIV: Frequency For High Cost of Labour And
Transportation

\begin{tabular}{|l|c|c|c|c|}
\hline \multicolumn{5}{|c|}{ HIGH COST OF LABOUR AND } \\
TRANSPORTATION \\
\hline VALID & F & P (\%) & VP (\%) & CP (\%) \\
\hline Very low & 8 & 8 & 8 & 8 \\
\hline Low & 13 & 13 & 13 & 21 \\
\hline Medium & 41 & 41 & 41 & 62 \\
\hline High & 22 & 22 & 22 & 84 \\
\hline Very high & 16 & 16 & 16 & 100 \\
\hline TOTAL & 100 & 100 & 100 & \\
\hline
\end{tabular}

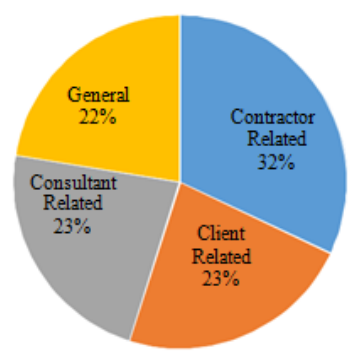

Fig 1: Response rate

\section{RESULT AND DISCUSSION}

The study identified and ranked the five most critical claim factors out of 44 selected claim factors. The factors classified into four different phases of construction. The highest frequency and impact of events justifying the right to claim on contractors, consultant and client-side and general are

- Quality of contractor's work Planning and management

- Fund arrangement and cash flowl

- Change the order during construction and market inflation

- Site management and supervisions

This study explored and ranked the causes of the claim. The above five factors are the major reason for the occurrence of the claim. The RII value for every five factors is the quality of the contractor's work is 0.712 . This is the highest value when compared to the other four. The next one is planning and management; the RII value is 0.673 . This is the second leading factors. The third one is fund arrangement and cash flow the RII Value is 0.673 . The fourth one is changing the order during construction and market inflation; its RII value is 0.651 . The final one is site management and supervision; its RII value is 0.631 . 
The above five factor's relative importance value is more when compared to the other thirty-nine factors.

In this study, all the forty-four factors are depending on each other. We had to rectify these factors out of 39 factors. Surely some factors index or impact of that factor will be reduced in construction.

\section{CONCLUSION}

Claims are the biggest challenges in meeting the construction industry nowadays. Finding the root cause is the first step to avoid the claim. This study aimed at identifying and ranking the causes of claims according to their relative importance in the construction industry. The study findings of the first thing are reasons for claims caused by owners, the second thing is reasons for a claim caused by the contractor, and the third thing is reasons for a claim caused by the client). This study is finding the main causes of the claim and understanding the claim and how to avoid the claim during construction. From the investigation, it is fitting that contractual workers select a decent venture supervisor who has a suitable involvement in development venture usage and learning of development guarantee. The undertaking arranging and configuration organize proprietors need to expand mindfulness inside the nearby network about the advantages of the construction project to keep away from obstruction from neighborhood occupants amid the task execution organize. It should be possible through leading formal reviews and workshops. Proprietors need to help contractual workers all the more viable in evacuating obstructions so a project can be actualized without deferrals. At long last, there must be a near-by collaboration between the contracting gatherings to control, limit and keep away from explanations behind cases happening on development ventures. This is the important to diminish reasons for cases and as needs is limiting postponements and cost overwhelms on development ventures. The discoveries introduced in this examination give some direction and data that directors and industry specialists can use to deal with their tasks.

\section{REFERENCES}

1. Abdul-Mala.: "The five commandments of construction project delay analysis", Journal of Construction Engineering and Management, ASCE Vol.40, No.4, 1998.

2. Abebe Dinku and Girmay Kahssay.: "Claims in International Construction Projects In Ethiopia And Case Studies On Selected Projects"' Journal of EEA, Vol 20, September 2003.

3. Abhishek Shah, Rajiv Bhatt, J. J. Bhavsar.: "Types and Causes of Construction Claims", International Journal of Engineering Research \& Technology (IJERT) Vol. 3 Issue 12, December-2014. Construction Engineering and Management ASCE Vol. 120, No.3 1986.

5. Bu-Bshait and I.Manzanera.: "Claim Management", Journal of Construction Engineering and Management, ASCE Vol.8, No.4, 1990.

6. Chaitanya Khekale, Nityan and Futane. "Management of Claims and Disputes in the Construction Industry". International Journal of Science and Research (IJSR) Volume 4 Issue 5, May 2015.

7. Cook duke Cox tod and Kenny.: "Foundations of construction contracts", Journal of Construction Engineering and Management, ASCE January/ February 1998

8. D. A. Vlatas, "Owner And Contractor Review To Reduce Claims"., Journal of Construction Engineering and Management, ASCE Vol. 112, No. 1, March 1986.
4. Blaikie.P.M: "Claims by contractors against owners", Journal of

9. Dickman.J.E, Nelson.M.C, "Construction claims, frequency and severity", Journal of Engineering Research \& Technology (IJERT) Vol. 3 Issue 12, December-2012.

10. Edward J. Jaselskis, Jeffrey S. Russell.: "Predicting contract survey bond claims using contractor financial data", Journal of Construction Engineering and Management, Vol.120, No. 2, June 1994.

11. George F. Jergeas, Francis T. Hartman.: "Contractors Construction Claims Avoidance", Journal of construction engineering and management, ASCE Vol. 120, No.3,

12. G.K.Kululanga, W. Kuotcha.: "Construction Contractors Claim Process Framework". Journal of construction engineering and management ASCE July/August 2011.

13. Jeffrey S. Russell, Edward J. Jaselskis.: "Predicting construction contractor failure before contract award", Journal of Construction Engineering and Management, Vol.118, No. 4, December 1992.

14. Jeffrey S. Russell, Edward J. Jaselskis.: "Trends in construction contractor financial data", Journal of Construction Engineering and Management, Vol.119, No. 4, December 1993.

15. J. K. Yates and Alan Epstein.: "Avoiding and Minimizing Construction Delay Claim Disputes in Relational Contracting", Journal of professional issues in engineering education and practice, ASCE / April 2006.

16. J. K. Yates and Alan Epstein.: "Analytical Model for Analyzing Construction Claims and Opportunistic Bidding", Journal of construction engineering and management ASCE January/February 2004

17. Kandi.: Journal of Construction Engineering and Management, ASCE Vol. 135, No.9, September 1, 2009

18. Kraiem, Z. M and Diekmann, J.E.: "Concurrent delays in construction projects", Journal of construction engineering and management ASCE Vol. 120, No.3, September 1995.

19. M. A. U Mustafa, A. M., El-Saadi, M. H. \&Abou-Zeid, M. G.: "Process Model for Administrating Construction Claims", Journal of Management in Engineering, April 2002.

20. M. M. Kumaraswamy.: "Conflicts, Claims and Disputes in Construction, Engineering", Construction and Architectural Management, Vol.4, No.2, 1997.

21. Mukilan.K : "A Qualitative Study and analysis of causes of disputes in a claim in the construction industry", International Journal of Civil Engineering And Technology, IJCIET volume 10, issue 01, Jan 2019

22. Nor Azmi Bakhary, Hamimah Adnan, Azmi Ibrahim.: "Critical Review on Improving the Claim Management Process in Malaysia", Journal of Education and Vocational Research Vol. 4, No. 7, July 2013.

23. P. Levin.: "Construction Contract Claims", Changes \& Dispute Resolution", Journal of Construction Engineering and Management, Vol.34, No.2, 1992

24. R. K. Cox.: "Managing Change Orders and Claims", Journal of Management in Engineering, ASCE January/ February 1997.

25. S.Alkass, and F. Harris.: "Construction Contractor's Claims Analysis", Journal of Engineering and management, ASCE Vol.19, No.1, 1991.

26. Stephen Scott.: "Delay Claim in U.K. Contracts". Journal of construction engineering and management, September 1997.

27. Steve Scott, Richard Anthony Harris.: "United Kingdom Construction Claims", Journal of construction engineering and management, ASCE September/October 2004.

28. Wonkyoung Seo and Youngcheol Kang: "Performance Indicators for the Claim Management Process of Construction Projects", Journal of construction engineering and management ASCE January 2019

29. Dhaval Parikh; G. J. Joshi and D. A. Patel: "Development of Prediction Models for Claim Cause Analyses in Highway Projects" Journal of Legal affairs and Dispute Resolution in Engineering and Construction Volume 11 Issue 4- November 2018

30. Tak Wing Yiu, Tingting Liu and Lai Chun Kwok: "Explicating the Role of Relationship in Construction Claim Negotiations", Journal of Construction Engineering and Management Volume 144 Issue 2 February 2018

Published By:

Blue Eyes Intelligence Engineering 


\section{Influence of Claim Management in Construction Industry}

\section{AUTHORS PROFILE}

Mukilan K. Completed his Master of Engineering in the field of Construction Engineering and Management in RVS Technical Campus, Coimbatore in the year of 2015 .He completed his Bachelor of Technology under Kalasalingam University in the year of 2012. He has more than five years of experience in teaching. He has published various papers in the reputed journals. His main thrust research areas are Construction management

Ramesh Babu C. completed his Ph.D. from IIT Chennai. $\mathrm{He}$ has more than ten years of experience in teaching and research. His areas of research includes pervious concrete, geo polymer concrete, and high volume flyash concrete

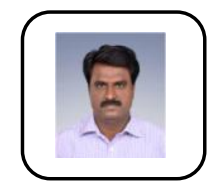

Muthukannan M. completed his Ph.D in Civil Engineering in Anna University, Chennai in the year 2010. $\mathrm{He}$ completed Master of Engineering in the field of Transportation Engineering and Management in College of Engineering, Guindy, Chennai in the year 2004. $\mathrm{He}$ completed his Bachelor of Engineering under Madurai Kamarajar University in the year 2000. He is presently working as a Professor in Civil Engineering department at Kalasalingam University, Tamilnadu, India. He is guiding for many $\mathrm{Ph} . \mathrm{D}$ scholars in the field of transportation engineering and computer applications in transportation network using graph theory. He has published various quality papers in the reputed journals. His main thrust research areas are transportation network design, transport management and travel demand management 